branched or even quite simple stems and squarrose leaves. A branch leaf, in cross section, shows the triangular chlorophyllose cells free on the inner side, characteristic of S. molle, whereas in S. rigidum they are elliptic, nearer to the outside, and on both sides completely included.

Neuruppin, Germany, Feb. 6, I89o.

\title{
Botanical papers at the Indianapolis meeting of the A. A. A. S.
}

The Indianapolis meeting was characterized by the great number of botanists and botanical papers in Section F. Of the 48 papers read before the section 28 were botanical. The series of papers upon the general subject of " The Geographical Distribution of N. Am. Plants " proved to be so successful that they were ordered printed in full in the volume of Proceedings, and will be issued also as a separate pamphlet reprint. Five of the seven papers assigned at the Toronto meeting were read, Professor C. S. Sargent being absent in Europe, and Professor John Macoun being engaged in exploration in the far northwest. Professors W. J. Beal and john M. Coulter, however, had papers upon geographical distribution, which were included in the series, making seven papers upon various divisions of the subject. It was also thought wise to prepare another botanical programme for the next meeting, to be held in Washington, D. C. The committee selected a physiological subject and made the following appointments: (I) The absorption of gases, by J. C. Arthur; (2) The aeration of aquatic plants, by W. P. Wilson; (3) The absorption of fluids, by L. H. Pammel; (4) The movements of fluids in plants, by W.J. Beal ; (5) Transpiration, by Chas. E. Bessey.

John M. Coulter was elected vice-president of the section for the Washington meeting.

Following are the abstracts of the botanical papers read before the section at Indianapolis, many of which will appear in full in the botanical journals, government reports, and the volume of Proceedings of the Association: \footnotetext{
Forest Trees of Indiana: STANLEY Coulter.-The au-
thor notes that the distribution of trees in Indiana depends upon the streams rather than upon latitude or elevation. The list contains ro6 species and is characterized by the abundance of Cupuliferæ (24 spp.) and the paucity of Coni-
} 
feræ (7 spp.). Of these the most remarkable is Taxodium distichum, which is found in considerable quantity in southwestern counties where it reaches its northern limit.

Preliminary notes on a new and destructive oat discase: B. T. GAlloway.-The disease ravaged the oat crop in all the states of the Mississippi valley this year. It is due to a micro-organism which has been grown in various culture media and the disease produced in oats by inoculation.

Observations on the variability of disease germs: THEOBALD SMrTH.-In studying hog cholera lately a form was discovered in addition to the one known since 1885 , which produces the same disease in a milder fashion. This led the author to consider the variability of disease germs.

Trimorphism in Uromyces Trifolii: Miss J. K. HowELL. - The paper is a record of cultures made to determine the connection of the three forms of spores which are associated with the rust on clover. It was found that the æcidiospores germinated at all times during the winter and as the result of their growth produced on the host abundant uredosori, thus proving beyond doubt that the assumed relationship between the æcidium and the other forms actually exists. B. T. GALLOWAY.-An account of the life-history of the fungus, giving the methods by which the author established the relationship between the various forms.

On the seed coats of the genus Euphorbia: L. H. PAMMEL.-This was a series of observations to ascertain diagnostic characters from the seed coats of closely related species. There was considerable variability in structure, but not of a kind to be used in the discrimination of species.

Observations on the method of growth of the prothallia of the Filicinea, with reference to their relationships: DougLas $\mathrm{H}$. CAMPBell. - The object of this paper is to defend the theory of the origin of the ferns from forms resembling liverworts and the results presented are derived from son of the early stages of ferns with those of liverworts. Such pecially in presents such remarkable resemblances, esnation seems method of growth, that no satisfactory explaorigin of the possible to the author, except that of a common iwo forms.

Development of the sporocarp of Griffithsia Bornetiana:
V. M. SPALDING. - The author showed the great variability 
in number and position of peripheral cells, including the one from which the trichophore is produced; also, the early formation of spore-producing cells, rendering it doubtful how far the production of spores is the result of fertilization. He also pointed out the differences between this and the closely related species $G$. corallina in the development of the sporocarp.

Contributions to the life-history of Isoetes: Douglas H. CAMPBELL.- An account was given of the nuclear division, preliminary to the iormation of the prothallium, and the development of the sexual organs traced, so far as the author's investigations had extended.

Geographical distribution of $N$. Am. plants: (I) The relation of the Mexican flora to that of the U. S., SEREno WatSoN ; (2) The distribution of N. Am. Umbelliferæ, JoHN M. Coulter; (3) The distribution of Hepaticæ of N. Am., LUCIEN M. UNDER WOOD; (4) The migration of weeds, Byron D. Halsted; (5) The distribution of N. Am. Grasses, W. J. BeAL; (6) The distribution of N. Am. Cornaceæ, JohN M. Coulter; ( 7 ) The general distribution of N. Am. plants, N. L. Britton. As these seven papers were essentially abstracts themselves and are to be printed together and in full in the volume of Proceedings, no further mention need be made of them in this report.

\section{Work of the Botanical Division of the Dep't of Agricult-} ure: F. V. Coville.-The author gave an account of the work of the division in the way of exploration, publication of "Bulletins " and "Contributions," amount of money appropriated, etc., all of which was of great interest to botanists, who are all desirous of encouraging a thorough exploration of the country and the competent and speedy publication of results. A resolution was passed in the Section, adopted by the Council, and read in general session, calling the attention of the proper authorities to the fact that the valuable botanical collections now in the Department of Agriculture are not properly protected against fire, and urging the necessity of erecting a fire-proof building as soon as possible. The continuity of protoplasm throngh the cell-walls of
plants: W. J. BEAL and T. W. TuOMEY.-The authors had examined the cortex of 75 woody or shrubby plants, with the view of discovering the most favorable for the demonstration of protoplasmic continuity. While it was thought that in some rare cases the connecting protoplasmic strands were 
large enough to be readily visible, in the vast majority of cases the exceedingly delicate fibrillæ penetrating the middle lamellæ required for demonstration the highest powers of the microscope, and the most delicate manipulation.

Potato-scab, a bacterial disease: H. L. Bolley.-By special arrangement, this paper, which belonged to the Section and will so appear in the volume of Proceedings, was read before the Botanical Club, and appears in that connection in our report.

The development and function of the so-called cypress" knees," with a consideration of the natural habitat of the tree: W. P. WILson.-Dr. Wilson has for several years been investigating this subject, both by means of numerous cultures and by the examination of great cypress tracts in Florida. He described four methods by which the "knees" are formed, and demonstrated that their formation always had to do with the presence of water, so that they could be produced at will in cultures. The cypress was originally a dry ground tree and this structure was an adaptation to a watery habitat. The "knees" are rapidly formed in the presence of water, and gradually rot away and disappear when water is withdrawn. A large and recently drained cypress region in Florida gave the author many proofs of this relation between the presence of water and the formation of " knees." It seems clear enough, therefore, that the function of the "knees" is the aeration of the root-structures. The paper was illustrated by a series of photographic lantern slides. The presence or absence of water not only affected the development of "knees," but the whole habit of the tree as well; as dry ground trees are tall and sparsely branched. while in water they are compact and flat-topped. The paper was exceedingly interesting, and bearing as it does upon a somewhat disputed subject, it is a gratification to know that it will soon be published and amply illustrated, the author's remarks before the Section being but a brief summary of some of the results obtained.

Preliminary note on the genus Rhynchospora in N. Am.: N. L. BRITTON.-The author outlined the grouping of species
of which he has made a most thorough study, and illustrated his remarks bs made a most thorough study, and illustrated

\section{an exhibit of specimens.}

N. L. BRITton, a new genus of Vacciniacea from Bolivia: group of epiphytic - The new genus belongs to the remarkable them all in general forms, and in its narrow leaves differs from 
Notes on a monograph of the gemus Lechea: N. L. BRITTON.-The study of this perplexing genus is in the nature of a heritage to Dr. Britton from Mr. Wm. H. Leggett, who did much toward its elucidation. It is especially confused by the numerous species of Rafinesque, most of which seem almost impossible of identification.

The specific germ of the carnation disease: J. C. ARTHUR and H. L. BolLEy.-In the absence of the authors this paper was read by title, but the abstract indicated the demonstration of a bacterial disease.

Notes upon plants collected by Dr. Ed. Palmer at La Paz, Lower California, in I890: J. N. Rose.-This paper represented part of the work being done by the Botanical Division of the Department of Agriculture. Dr. Palmer's collections from Lower California have brought to light many new and interesting plants, and $\mathrm{Mr}$. Rose has long been engaged in their study. The present paper will appear in nne of the forthcoming "Contributions from the National Harbarium."

Notes upon crystals in certain species of the Arum family: W. R. LAZENBY.-The relation of these crystals to acridity was discussed, the author having investigated a large number of cases, and inclining to the belief that the rhaphides are to be looked to as the explanation of acridity.

Notes on Isopyrum biternatum: C. W. HaRgitT.-Professor Hargitt has been making a study of the tuberous rootswellings of this species, both as to their structure and contents. A preliminary notice of his results appears in this number of the GAZETTE.

\section{Meeting of the Botanical Club at Indianapolis.}

The Botanical Club had a very large and enthusiastic attendance, with no lack of papers or interest. The minutes of the meeting, as being of interest to all botanists, are published as follows:

The eighth annual meeting of the Botanical Club of the A. A. A. S. was called to order at 9 A. M. by the President, Dr. N. L. Britton, of Columbia College, New York, Professor C. R. Barnes being secretary. In accordance with the request of the Toronto meeting the President opened the proceedings with a brief résumé of the present state of systematic botany in North America. He gave a synopsis of 


\section{$2 \mathrm{BHL}$ Biodiversity Heritage Library}

1890. "Botanical Papers at the Indianapolis Meeting of the A. A. A. S." Botanical gazette 15(9), 227-231. https://doi.org/10.1086/326564.

View This Item Online: $\underline{\text { https://www.biodiversitylibrary.org/item/90530 }}$

DOI: https://doi.org/10.1086/326564

Permalink: https://www.biodiversitylibrary.org/partpdf/221994

\section{Holding Institution}

Missouri Botanical Garden, Peter H. Raven Library

\section{Sponsored by}

Missouri Botanical Garden

\section{Copyright \& Reuse}

Copyright Status: Public domain. The BHL considers that this work is no longer under copyright protection.

This document was created from content at the Biodiversity Heritage Library, the world's largest open access digital library for biodiversity literature and archives. Visit BHL at https://www.biodiversitylibrary.org. 